[Published as Prinz, Janosch (2016): Raymond Geuss' Radicalization of Realism in Political Theory. In: Philosophy and Social Criticism 42 (8): 777-796.] Accepted for publication 01 April 2015

\title{
Raymond Geuss' Radicalization of Realism in Political Theory
}

Janosch Prinz

\section{Abstract}

Raymond Geuss has been viewed as one of the figureheads of the recent debates about realism in political theory. This interpretation, however, depends on a truncated understanding of his work of the past thirty years. I will offer the first sustained engagement with this work (in English and German) which allows understanding his realism as a project for reorienting political theory, particularly the relationship between political theory and politics. Iinterpret this reorientation as a radicalization of realism in political theory through the combination of the emphasis on the critical purpose of political theory and the provision of practical, contextual orientation. Their compatibility depends on Geuss' understanding of criticism as negative, of power as 'detoxified' and of the critical purchase of political theory as based on the diagnostic engagement with its context. This radicalization particularly challenges the understanding of how political theory relates to its political context.

\section{Introduction}

Raymond Geuss' recent work has been received as an important contribution to realism in political theory. ${ }^{1}$ One could go as far as to claim that second only to Bernard Williams, Geuss counts as a figurehead of the recent debates about realism. ${ }^{2}$ Geuss certainly shares a number of the core criticisms of the realists, including the rejection of ideal theory and idealization, moralization and the legalism of liberal-normative political theory. ${ }^{3}$ However, as 
far as Geuss has been invoked as an example of realist criticisms of 'high liberalism' it has been at the cost of a differentiated and nuanced account of his position, either reducing him to a member of the realist "ragtag band"4 or mischaracterizing his position as leaving the remit of political theory through concentration on power or history alone, thus eschewing the task of philosophical justification. ${ }^{5}$

Despite the popularity of Geuss' writings since the publication of Philosophy and Real Politics and the earlier judgments that his writings are refreshing for political theory or even radically innovative and pose a challenge to the current orthodoxy in political theory, ${ }^{6}$ the judgment of Glyn Morgan that 'Geuss' writings have attracted far less critical attention than they deserve $[\ldots]^{\prime \prime 7}$ still more or less holds true. More specifically, the distinctiveness of Geuss' realism and its potential for radicalizing realism has thus far not been discussed in depth. ${ }^{8}$ I will redeem this lack through offering the first sustained interpretation of Geuss' realism taken on its own terms. Thus interpreted, Geuss' realism offers a more radical reorientation of political theory than the accounts of realism which have dominated the debates of the past five years. More specifically, the interpretation seeks to show that Geus s' understanding of realism has the potential to combine the ambitions for practical orientation and subversively critical evaluation of a political context.

For these purposes, I will outline the distinctive features of Geuss' realism and then briefly relate them mostly to the limitations of the recently prevalent accounts of realism in political theory. The distinctive features of Geuss' realism to be considered here - Geuss' understanding of the purposes of political theory and of criticism, of power and of how political theory should try to relate to the political context into which it intervenes, and of politics - are also key for these realist political theories. I will concentrate these comparisons on those realists who have offered the most incisive criticisms of liberal-normative political 
theory and have done the most for positively developing realist political theory. ${ }^{9}$ These are the realisms inspired by Bernard Williams. ${ }^{10}$

\section{Political theory as a critical activity of negative criticism}

I will start by considering Geuss' views on purposes of political theory. This leads to a discussion of his understanding of criticism. Geuss argues that under current political circumstances, political theory should mainly "contribute to enabling 'thinking differently' (penser autrement) [...]. A philosophy which is true to the best of its traditions, should refrain from delivering additional 'philosophical grounding' for what already exists, for our contemporary liberal-democratic social order." ${ }^{11}$ Rather, the principal task of political theory is to critically examine one's political context. ${ }^{12}$ Geuss serves this task through using what one could call the triangulation of conceptual history, genealogy and criticism of ideology for the examination contemporary political theory, politics and their relationship. ${ }^{13}$ These 'methodological choices' support Geuss' commitments to self-reflection, particularly about the relationship between political theory and its political context (but also about the relationship between the methods and goals of his realism), and to negative criticism. His evaluation of political theories is to a considerable extent driven by the criterion of whether the theory in question reinforces or questions those aspects of the political order which are taken for granted. ${ }^{14}$ For him political and moral theories cannot help but be connected to the ir political context and it is the task of the theorist to critically reflect on the terms of the relationship. ${ }^{15}$ His limitation to the interrogation and questioning of the status quo further points to his commitment to negative criticism. His preferred negative understanding of criticism is crucial for grasping how he understands the critical orientation of political theory: 


\begin{abstract}
"In the political realm appeals to the need for 'constructive' criticism can in principle represent a (generally laudable) attempt to remind those involved in some evaluation of human action of the need to remain aware of a kind of internal demand under which such criticism operates, namely of the need to keep Tschernyschevsky's (and later Lenin's) central question 'What is to be done?' firmly in mind; in fact, however, the demand for 'constructive criticism' in general functions as a repressive attempt to shift the onus probandi and divert attention from the possibility of radical criticism." 16
\end{abstract}

Geuss sees this as connected to the tendency of human societies to inertion, which generates status quo-conserving mechanisms including the constructiveness condition of criticism. ${ }^{17}$ For Geuss the constructiveness condition of criticism is especially problematic because it leads to a more or less tacit acceptance of the frameworks of reference of the target-agents of criticism, which means the domestication of the criticism, given that it must be comprehensible for those target-agents: "[According to the constructiveness condition] I must criticise them (and their actions, the institutions in which they participate, etc.) in a way that conforms to what 'they' define as what they can 'reasonably' be expected to do and results they can 'reasonably' be expected to accept". ${ }^{18}$ This should probably be understood as an explicit attack on the Rawlsian language of the liberal principle of legitimacy ${ }^{19}$ - the point Geuss is trying to make is that the radical potential of criticism is lost if one "allow[s] the existing social formation to dictate the terms on which it can be criticized [...]". ${ }^{20}$

The rejection of the constructiveness condition, however, does not mean that Geuss is not interested in how criticism relates to its specific context, how it becomes intelligible, as what is 'constructive' for us may not be so for others. To the contrary, he stresses

\footnotetext{
"the extreme importance in criticism of notions like possibility and necessity, alternative identities and courses of action, which points in what framew ork are taken to be fixed and which are taken to be variable. This in turn raises important general issues about the malleability of human nature and institutions, and the possible limits of such malleability, utopianism, tragic or otherwise
} 
irresolvable forms of conflict, and the 'substitutivity' of goods, services, practices, and institutions." 21

After all, Geuss holds that "[p]art of what politics is about is that we wish to be and live as people of a certain kind". ${ }^{22}$

This shows that Geuss' position is not simply a flat-out rejection of the idea that criticism can or even should be action-oriented and -orienting, but rather an attempt to operate criticism in political theory at a higher level of self-reflection. The (rejection of the) constructiveness condition requires substantial self-examination with regard to who we are and what can, for us, count as constructive and how this limits criticism. This seems to offer a fruitful way for engaging the tension between the goal of practically oriented and guiding political theory and political theory as potentially radically subversive criticism.

The form which Geuss' negative criticism actually takes is an eclectic mix of tools for questioning, interrogating and problematizing the present use of concepts and their history as well as selected aspects of the political present. What Geuss calls - in reference to Foucault ${ }^{23}$ - the ethos of enlightenment or of critique, "[a] set of attitudes, habits, and practices connected with continual criticism and self-criticism, and in general an openness to new experience", ${ }^{24}$ underlies Geuss" work on the "exercise of analytic abilities, of the imagination, especially the constructive imagination of alternatives to present ways of doing things, of discriminatory skill, and of judgment". ${ }^{25}$ Geuss' realism is propelled by this negative understanding of criticism which underlies its examination of the status quo, and which is instrumental to the goal of opening up ways for thinking and acting differently, e.g. practically subverting the (conceptual) order of the present, the suspension of judgments or through the work on conceptual experimentation and innovation (more on which below). 


\section{The diagnosis of power relations and the entanglement between description and evaluation}

The combination of the emphasis on the examination of one's political context and the view that the purpose of political theory is principally critical leads to a tension with the rigid distinction between descriptive and normative forms of political thinking common in postRawlsian liberal-normative political theory. Geuss programmatically rejects this distinction. ${ }^{26}$ Due to the temporal and perspectival conditions under which politics and the study of politics take place, 'in an arena in which the standards for evaluating what is 'success', what is a good idea, what is a desirable outcome, are themselves always changing and always in principle up for renegotiation", ${ }^{27}$ the idea of purely normative ideas - ideas whose nor mative authority is based on their claim to be maximally distant from the particularities of politics is unhelpful, particularly in the face of day-to-day phenomena which need to be dealt with, understood and evaluated.

In order to assess the specific horizon for these changes and renegotiations, which for Geuss are such a central aspect of political theorizing that he terms it "a kind of experimental science (of concepts) [eine Art (begriffliche) Experimentalwissenschaft]", a deep grasp of the context in question is required. ${ }^{28}$ Rather than engaging in the mastery of principles and theories, Geuss holds, diagnosis is key for a critical and practically oriented understanding of political theorizing:

\footnotetext{
"Instead of looking for general principles, one should rather engage in the diagnosis of one's current context (Zeitdiagnostik treiben): What are the pressing problems, what the most acute dangers of the present? [...] Only in conjunction with an always quite complex diagnosis of the current situation, which interprets given facts in relation to possible, future developments which are partly dependent on our actions, and in relation to our factual structure of hope and fear, is, I hold, a somewhat defensible and politically relevant ethics thinkable."29
} 
This diagnosis combines phenomenological and genealogical elements in order to produce local, practical knowledge about and for a specific context. ${ }^{30}$ It is oriented toward (identifying) problems and aims to provide some orientation for how to address these problems. The diagnosis has to deal with such a mass of phenomena which are also in flux that it will always remain to some extent incomplete, indeterminate and contestable. The challenge of diagnosis is further complicated by the fact that contemporary societies are "hyper-complex structures", i.e. structures which contain an account of themselves as structures, in which the diagnostician is herself embedded. ${ }^{31}$ For the purposes of diagnosis, not the dichotomy between an ideal world and a real one corrupted by power - a choice which contributors to the realist literature at least view as possible ${ }^{32}$ - provides orientation for making decisions, but rather these decisions always take place within a welter of half-baked views and incomplete knowledge:

"The difference between truth and its opposites, and between more admirable and less admirable forms of politics, is not a difference between a disembodied realm of ideal discourse and the sordid world of interests, powers, and complex motives but a distinction within this latter world the real one which we in any case always inhabit." 33

These conditions underscore that the diagnostic process is an exercise of interpretation (for which ideal theory abstractions are not helpful), which is rather reflective and conceptual - depending on the experimentation with concepts in order to be able to identify problems than a collection of empirical data. ${ }^{34}$ How the focus of the examination is selected and how the phenomena in it are classified and compared will depend to a considerable extent on the presuppositions which are brought into the diagnostic process. Diagnosis is thus not a purely descriptive task, but also entails normative aspects through the need to position oneself to the object of study which brings the entanglement between descriptive perspectives and evaluations into Geuss' focus. Instead of looking for a set of normative principles to order a 
political context, Geuss focuses on the forms of normative thought which are always already present within a particular context and which, with Michael Theunissen could be called the "inner normativity of historical reality" or of the present. ${ }^{35}$ This is why the application of diagnosis to political questions especially requires self-reflection on and explication of these presuppositions. This means, in short, that questions of normative orientation are already answered in a specific context and the task of ethical reflection through political theory is hence not the abstract quest of normative grounding or (even) justification, but engaging these answers:

\footnotetext{
"Ethics is not a closed, nor at all finalizeable set of doctrines, as long as human life, as we know it, does not change its basic structure. Ethics is a perpetual practice, namely a continuous activity of reflection. As we de facto are always already moving in a field full of seeming authorities, it is not as important to ask abstractly how one could at all submit to something like an authority, as to direct specific questions at concrete claims to authority and validity [gegenüber konkreten Geltungsansprüchen]. Asking questions, after all, is also one way to act and - as Socrates felt on
} his own body - one which is not always free of danger." 36

The examination of the present on which the ability to ask such questions depends will already be characterized by selections of foci and reactions to the normative claims of the present which make this superficially descriptive task entangled with normative aspects. The asking of particular questions, for Geuss, counts also a kind of political action and marks the practical orientation of critical and self-reflexive political theory as interrogating concrete problems. This may seem an extreme position denying the possibility of finding anything but very local criteria for evaluation and might seem to question the point of philosophical criticism. However, Geuss' point is rather that the specific claims to authority in question cannot be reduced to being an instantiation of a (more) general set of principles, but that the criteria for their evaluation should be generated from the diagnosis of the specific context. This view does not preclude the possibility of criticism with transformative goals which, if 
successful, will likely contain a context-transcending outlook e.g. through the innovation of new conceptual vocabulary to grasp a situation as problematic and political. It only means that evaluative criteria (and the context-transcending outlook) can only be developed from within the specific context.

His emphasis on the entanglement between descriptive and normative aspects of political theory also leads Geuss to skepticism with regard to the possibility of the separation between the methodology of political theory, political theory, and politics. His understanding of realism regards political theory as partisan, as embroiled in power relations and potentially as political action. He particularly emphasizes the questions of how liberal-normative political theory is ideologically connected to the current political status quo. This underscores the need for a closer scrutiny of the relationship of political theory to its political context. This requires interrogating the framework of liberal-normative political theory, including its focus on normativity, normative principles and its philosophical toolkit. ${ }^{37}$ Recognizing the involvement or rather entanglement of political theory in relations of power further underscores for Geuss the need for self-reflection of realism in political philosophy:

\footnotetext{
"A realistic attitude has to put the possibility on the agenda that one can become engaged in a certain society in one way or another. As taking a realistic attitude is in itself an action, for which one needs to decide - nobody becomes a theorist, let alone a critic, of one's society without his or her own involvement - realism always needs to reflect upon itself and its possibility, otherwise it would be naïve." 38
}

This is compatible with viewing the redemption of the lack of reflection on historical, sociological or psychological questions as a principal task of political theory. ${ }^{39}$ However, Geuss is well aware that purging all illusions is itself an illusion and that political theory is itself always potentially ideological in a pejorative sense. ${ }^{40}$ 
The most important concept and set of actions for a negatively critical and selfreflexive diagnosis of the present are relations of power, often especially in their indirect impact on the reflection on these relations through ideological illusions, wishful thinking, and the taking for granted of day-to-day evaluations. ${ }^{41}$ Even if Geuss states in Philosophy and Real Politics that 'to think politically is to think about agency, power, and interests, and the relations among these", ${ }^{42}$ the focus on relations of power does not imply a view of power as a kind of totalizing iron cage or as a materialist antidote to culture. ${ }^{43}$ Geuss further rejects the view of power which is usually somewhat crudely attributed to classical IR realists as proponents of a kind of Realpolitik, i.e. power as the capacity to push through one's interests by any means which makes power a crudely understood commodity. ${ }^{44}$ In contrast to the tendency to look at power from a normative point of view, which binds the normative hold of power to it being rightful and characterizes most of the history of Western political thought, power as right, ${ }^{45}$ Geuss does not view power as in itself normatively problematic. ${ }^{46}$ For him power is a useful concept for analyzing historical (genealogy) and sociological (criticism of ideology, to be appropriated for local, not global criticisms of ideology) limitations of the perspectives that people can have on themselves and their specific context, with a focus on questions of collective action. ${ }^{47}$ This should be read as an attempt to overcome the view of the concept of power as normatively negative, or even as 'poisonous', which prevents its discussion and evaluation beyond the division between legitimate and illegitimate power. Power is, however, not the only relevant factor, but nearly always a relevant factor, for the diagnosis of a political and social order. This view is encapsulated in Geuss' thus far undeveloped idea of the "detoxification of power" ${ }^{48}$ It makes most sense to develop this idea against the background of the shift of the understanding of power which can be found in Foucault's later work on governmentality, ${ }^{49}$ in which techniques of power and the rationalities of governing are in focus, not the questions of legitimacy and the 'rightfulness' 
of power. ${ }^{50}$ In a characteristic passage Foucault formulates the change of perspective on power as follows:

"Not to ask oneself: is power good or bad, legitimate or illegitimate, a question of right or of morality, but to try, simply, to strip the question of power from all the moral and juridical framew ork, which has affected it up to now, and ask this naïve question which has not been asked that often, even if effectively a certain number of people have been asking it for a long time: what do relations of power, at their base, consist of?"'51

Thus understood, the detoxification of power then means to view power not as (necessarily) normatively negative, not as to be evaluated in moralized terms, but in terms of first asking what power means in a specific context and then analyzing its effects, both creative and limiting or destructive. Power is not per se good or bad but potentially dangerous. If the exercise of power with regard to collective action is characterized by what Foucault calls "conducting conduct" of oneself and others, ${ }^{52}$ and if such power relations are present in quotidian practices such as communication, then the question is not how to be free from power, but how to problematize, make visible and eventually minimize domination relationships. ${ }^{53}$ For this purpose, the strategies and techniques of power require close analysis, beyond the relationships between state and citizens (especially if understood as a conflict between authority and autonomy). ${ }^{54}$

In Geuss' writings this is expressed in the centrality of the question, "who does what to whom for whose benefit?", ${ }^{55}$ which has to be read as a guideline for the negative-critical diagnosis of certain aspects of the political present, e.g. what power techniques propel the distinctions between wants and needs, ${ }^{56}$ or what are the power techniques and strategies which allow liberal political theory to be viewed as advancing egalitarian goals? ${ }^{57}$ The concentration on techniques and strategies of power in the way that they affect how people govern themselves and others, on such relations of power in quotidian realities, does not 
mean a 'flight from philosophy'. Rather philosophical tools are used to enable the perception, understanding and interpretation of these power relations. Thus understood, the detoxification of power has important implications for the understanding of political theory as a critical activity. Whilst the detoxified view of power does not come with an inbuilt condemnation of power, it still does not diagnose relations and techniques of power for the sake of description only. This raises the question of the criteria for evaluating relations of power. Providing an answer to the question of how an understanding of power close to the later Foucauldian view is compatible with the critical project, as which Geuss' realism has been presented thus far, would be a way to counter this worry about the lack of normativity. Actually Foucault himself offers a way to reconcile these two elements:

\footnotetext{
"Maybe philosophy can still play a role on the side of counter-power, on condition that, in facing power, this role no longer consists in laying down the law of philosophy, on condition that philosophy stops thinking of itself as prophecy, pedagogy, or legislation, and that it gives itself the task of analyzing, elucidating, making visible, and thereby intensifying the struggles that take place around power, the strategies of adversaries within relations of power, the tactics employed, and the sources of resistance, on condition, in short, that philosophy stops posing the question of power in terms of good and evil, but poses it in terms of existence." 58
}

Foucault's view of how the critical potential of philosophy, despite the rejection of its ambition to 'legislate' through moral principles, could be retained lends support to the view that it is compatible with a detoxified understanding of power, however, only if the selfconception of philosophy, in our case more specifically political theory, is amended to reflect its entanglement with the political and social order. As such a change of the self-conception of political theory is at the heart of Geuss' realism, we can accept Foucault's suggestion as one possible answer to the potential objection levied against the detoxification of power that it would be incompatible with understanding political theory as a critical project because of the lack of a normative foundation. Foucault's emphasis on self-reflection and self-critique of 
philosophy (and political theory), with regard to its relationship to different techniques of power as its main task, further underscores the compatibility of criticism with the idea of detoxifying power: "After all [...] the task of philosophy today could well be [to ask the following questions]: What are the relations of power in which we find ourselves and in which philosophy has become, at least for 150 years, embroiled?"59

Thus far Geuss has mostly questioned, interrogated and problematized contemporary conceptual schemata using conceptual analysis, genealogy and criticism of ideology. Whilst these schemata are an important element of the exercise of power and wider techniques and strategies of power (as a kind of governing in Foucault's sense), the development of Geuss' realism would greatly profit from being supplemented by broader criticisms of techniques and strategies of power, which Geuss has thus far only attempted tentatively in shorter pieces. ${ }^{60}$

In sum, Geuss' emphasis on the diagnostic task of political theory and his view about the normative character of such diagnosis - that normative claims are already inherent in a political context and need to be examined and that this requires political theory to relate to the normative claims inherent to this context in ways which are both descriptive and normative particularly brings the entanglement between descriptive and evaluative aspects of political theorizing to the fore. For such an examination of the present Geuss places special emphasis on the importance of contextual diagnosis, which then cannot be separated from his understanding of the purposes of political theory, i.e. to be subversively critical of the status quo. ${ }^{61}$ This is the basis for the reconnection of the critical purchase of political theory to the diagnosis of its political context. The detoxification of power shifts from understanding power as a normatively negative influence on potentially autonomous agency to the analysis of the effects of techniques of power and relations of power on a political and social order. 
Detoxified power is central to Geuss' aspirations for political theory to help provide a contextual understanding of politics, which is the prerequisite of concretely practically guiding criticism. The detoxification of power leads to changes in the way criteria for evaluating political regimes are generated.

\section{The Understanding of Politics and of what is Political}

What counts as political cannot be generally defined - rather what is viewed as a political question depends on the historical context. Geuss regards politics in the wider sense as "a way of seeing or considering the world", not "a special domain, like biology or astronomy”. ${ }^{2}$ "“This is a political matter' means it is a matter considered in some sense to be potentially in our power and up for decision, and which we have some potential interest in dealing with in one way rather than another". ${ }^{63}$ Geuss' narrower understanding of politics adds to the above "at least the threat of recourse to coercion, force, or violence", which is "presented as being not merely a fact to be accepted but in some way 'legitimate'." 64 This understanding certainly differs in emphasis from those realist understandings which focus on conflict and the conditions of legitimacy. ${ }^{65}$ However, one might also argue that Geuss' understanding of politics is not especially unusual when he claims that "[p]olitics depends, to

a great extent, on judging what is actual relative to what is possible". ${ }^{6}$ To make this judgment on the basis of this phrase alone would, however, miss the mark. The understanding of the key terms 'actual' and 'possible' and of how philosophical inquiry can add to their understanding is a useful key to a more nuanced view of Geuss' understanding of politics. Here it makes sense to start from the emphasis on the diagnosis of the present political context as a central element of Geuss' political theorizing. 
The actual for Geuss is not easily grasped. Political theorists are advised to approach their surroundings with suspicion, to be wary of what is alleged to be actual and to inquire into how this has come to be viewed as actual:

\footnotetext{
"I would contend that what is 'out there' is usually a farrago of truths, half-truths, misperceptions, indifferent appearances, and illusion that needs to be seriously processed before one can accept any of it as 'real'. [...] One specifically modern form of social control is to allow free expression of all opinions, thus creating a chaotic landscape of informational overload in which potentially important facts simply get lost in the welter of surrounding nonsense, and important connections cannot be made." ${ }^{\circ 7}$
}

Geuss does not, however, embrace an essentialism of the real, but rather uses this attitude of suspicion in order to motivate criticism through diagnosis, the suspension of judgment or distancing of oneself, e.g. from the conglomerate of 'liberal democracy'. ${ }^{68}$ Rather than trying to unmask the 'real', Geuss is interested in attempting as thoroughly as possible to account for the history of the present, including the contingency (through genealogy) and the forms of distortion (through criticism of ideology) which could offer 'us' a different perspective on the questions within our collective agency. ${ }^{69}$ This could be taken as a commitment to the claim that only that which has a history is relevant for political theorizing which leads to the view that what is concretely political can only be determined in and for a specific context. This hangs together with the question of agency. Politics is about the reflection on the limits of agency in a collective mode in a specific situation and 'to fail to appreciate the radical difference between individual action and institutionalized forms of collective action is to miss the point of politics". ${ }^{70}$ Political theory needs to ask how the institutionalized forms of action in question have become the centre of the possible actions for structuring living together. ${ }^{71}$ For the diagnosis of the actual and the possible thus premised, Geuss views actions and contexts of action as much more salient than opinions, 
especially if these are the opinions of individuals abstracted from their context. ${ }^{72}$ This is the sense in which one should understand Geuss' claim that, "[p]olitics is a craft or skill, and ought precisely not to be analysed, as Plato's Socrates assumes, as the mastery of a set of principles or theories". ${ }^{73}$

Similarly, the possible is not easily limited either. To what extent can one, from the point of view of the present, predict the limitations of the possible for the future? Geuss is concerned with the danger of a too narrow understanding of the possible and invites utopian thinking in political theory. However, how he understands 'utopian' needs to be qualified. The utopian is not the drafting of blueprints. Rather, similar to the rationale for negative criticism and contextual diagnosis, it is primarily a tool for reflection about one's present situation.

The originality of Geuss' view of the utopian, especially with regard to the discussions of realism, lies in his attempt to break the hold of the view that a realistic political theory should be non- or even anti-utopian: "A realistic assessment of the situation means one which is not marred by wishful thinking, ideology or being stuck in taking for granted the quotidian evaluations (Befangenheit in den Wertselbstverständlichkeiten des Alltags). 'Realism' in this sense is not at all necessarily anti-utopian." ${ }^{\text {74 }}$ Rather, realism is not primarily opposed to utopian thought but to ideological thought and should be open to the cultivation of the utopian imagination:

"There is a pole of realism and there is a pole of utopianism. There is a pole which tells you don't be a victim of wishful thinking, don't be a victim of ideological illusion, don't be a victim of various kinds of repressive identities, and then there is a pole of cultivating what you want and taking your desires seriously and clarifying them, even if they are utopian in their content, even if they can't be satisfied in the life that we lead. And it seems to me that both of these things are an 
important part of [realism]. [...] Political philosophy has to be both fully realistic and fully utopian."75

This emphasis on the interplay between diagnosis and the utopian imagination needs to be related back to the view that politics is a kind of craft or art. Really significant political action (including political theory) does not conform to existing rules:

\footnotetext{
"Really significant political action, however, is action that, for better or for worse, neither simply conforms to existing rules, nor intervenes [...] to find craftsmanlike solutions to specific problems, but that changes a situation in a way that cannot be seen to be a mere instantiation of a preexisting set or [sic] rules. It creates new facts, violates, ignores, or even changes the rules. Such action may, like significant original art, be extremely rare, but the fact that such disruptive change of existing systems of action is always at least a possibility is one of the things that gives politics its special character." 76
}

From this point of view a political theory needs to be able to accommodate the emotional, the non-rational and non-systematic elements of politics, and reflect on the kind of intervention into politics which it cannot help but make. ${ }^{77}$

In summary, political theory should focus on the actual, but should view it through the orientation toward the possible in order to connect to the possibility of thinking and acting differently, i.e. to the criticism and the transformation of the actual. Geuss' realism in its understanding of politics interrogates both the actual and the possible in order to enhance 'our' understanding of our present situation and so allows for the consideration of the tension between the actual and the possible as an important focus of political theorizing.

\section{Geuss' realism as a radicalization of realism}

The preceding interpretation of key features of Geuss' realism sought to outline its distinctive position in political theory. Now the contrast to a selection of limitations of the 
prevalent understandings of realism in political theory will bring its potential to radicalize realism to the fore. Realism in political theory has been received as a more or less incisive challenge to the post-Rawlsian liberal-normative mainstream. However, the tensions between the realist departures from this mainstream, and where realists remain committed to it, have not been investigated thus far. Whilst a general discussion of the limitations of the departur e of realist criticisms from liberal-normative political theory and their positive development of realist political theory would require a more detailed treatment than can be offered here, I will briefly discuss how the distinctive features of Geuss' realism depart from the positions taken by (the most critical and developed) realist political theories. ${ }^{78}$

More specifically, I will focus on the question of how realists have attempted to relate their normative-critical to their practical ambitions. Despite the concentration of much of the debates about realism on the criticism of the critical purchase of moralism and ideal theory, realists have thus far mostly neglected the question of how their political theories can generate critical purchase, without taking recourse to an understanding of normativity based on moral criteria. ${ }^{79}$ In view of this lacuna, Sleat has recently argued that realism is in need of "the development of a critical realist theory", ${ }^{80}$ which, however, would need to be based on an understanding of critical distance which does not depend on a moral criteria. However, realists have neither delivered any appropriate critical perspective, nor have they engaged in rethinking the critical purchase of their political theories. The only device that could be viewed as developed for these purposes by realists, Bernard Williams' Critical Theory Principle, ${ }^{81}$ may be viewed to reintroduce moral criteria through its adherence to notion of freedom linked to the concept of autonomy. Rather realism has been characterized as only covering the contextuallyembedded and practically oriented facet of political theory, ${ }^{82}$ thus neglecting its critical task. This has led to a division of labor between political theory which uses context-transcending moral standards for criticism, but it is also politically impotent and political theory which 
focuses on 'facts' of politics in a specific context, guides action within this context, however, lacks the resources to criticize the status quo of this context. This is the shorthand for the dilemma which is the basis of an argument for the division of labor which can be found in the debates. ${ }^{83}$ This particular dichotomy limits the horizon of the debates about realism by inhibiting the discussion of a radically critical and contextualist realism. Whilst this affects realists primarily interested in non-ideal theory the most, Williamsian realism is also affected, e.g. Sleat's realist theory of legitimacy, which is based on the congruence between the rationale of legitimation offered by a claimant to authority and the beliefs of its addressees. His theory is characterized by the tension between the danger of being unable to distinguish the fabrication of such a congruence on the basis of the extant power (alone, or at least predominantly) of the claimant to authority from a congruence which is based (predominantly) on other reasons, without taking recourse to an understanding of critical distance. ${ }^{84}$ The development of a critical perspective appropriate to realism is in part inhibited by its anti-utopian orientation. This orientation is one of the basic features of realism which are derived from its opposition to Rawlsian political theory, in as far as 'utopian political theory' denotes theories which are overly ambitious with their agenda for change. ${ }^{85}$ Utopianism is seen as a problem both in terms of the action-guidance of a theory, e.g. through its lack of feasibility, ${ }^{86}$ and in terms of the potential spiral of violence following disappointed hopes triggered by the foundering of utopian projects. ${ }^{87}$ This focus on conflict is the background assumption behind the emphasis on the anti-utopian form of most realist theorizing. Instead of utopian fantasy the appropriate focus of political theory is deemed to rest on order and stability which may lead to political conservatism, namely a tendency to affirm the status quo, given how difficult it is to predict the effects of political change so that change could be known to be compatible with order and stability. ${ }^{88}$ 
Geuss' realism avoids the abstract and reductive dichotomizations as which the differences between liberal-normative political theory and realist alternatives could be schematically portrayed between descriptive and normative, consensus- and conflictcentered, or even optimist and pessimist approaches due to his emphasis on the need for close critical and diagnostic examination of the 'actual'. In order to get to a perspective through which one can make informed judgments of one's political context, Geuss invites the student of politics to approach her political context through a variety of perspectives which make use of philosophical tools such as conceptual analysis, criticism of ideology or genealogy which are not used for thought exercises of comprehensive abstraction, but rather for the examination of the empirical realities as well as, based on this examination, thought exercises of making the familiar strange. For the latter the (potentially utopian) imagination is a key resource. These diagnoses and thought exercises are motivated by a negative impulse to start from problems or with the problematization of the status quo.

Geuss' realism is characterized by engaging the tension between the descriptive and normative aspects of political theorizing. From his point of view political theory should aim to be practically oriented and orienting, yet at the same time should try to achieve this through diagnosis of the respective political context led by potentially radically subversive criticism. ${ }^{89}$ Geuss thus offers an intensification and opening of our self-examination. The depth of his (self-) examination which starts with problematizing and questioning the pre sent is illustrated by the questioning of the coherency of the 'basic structure' of their discourses which is the moral and political vocabulary centered on concepts like justice, rights, political authority, and legitimacy. ${ }^{90}$ For this endeavor he takes seriously the importance of discursive power, or rather, the power of interpretation, viewed as a kind of action. His rejection of the constructiveness condition of criticism enables subversive criticism, but also leaves open a tension between the practical orientation and radically subversive and critical outlook of his 
realism. To substantiate the distinctiveness of his perspective, further work on his change of the bases of critical purchase of political theory is required. Whilst Geuss rejects philosophical claims to objectivity as a basis for political authority, ${ }^{91}$ he reserves space for philosophical tools to offer a somewhat superior perspective on and thus to affect the selfconception of the agents involved and their assessment of their situation. ${ }^{92}$ The importance of this tension for Geuss' realism points to the need for the development of a different understanding of critical distance, led both by the critical impetus of philosophy to examine oneself and one's environment and by taking seriously the everyday actions which form the object of the political context as the basis for offering practical orientation.

Overall the potential of Geuss' realism to radicalize realism consists of his emphasis on the relationship between theory and its political context in terms of how they influence each other further focus and on the entanglement between the normative and the descriptive in political theorizing, as well as on the entanglement between the impulses of a political theorist for intervention and reflection, and between the analysis of seeming political necessities and the potentially utopian political imagination. How these entanglements and tensions are best addressed is still open to question, yet bringing them into view provides a potentially fruitful starting point for engaging them in a radicalized realism.

\section{Conclusion}

Raymond Geuss' understanding of political theory as a self-reflective intervention into politics driven by the task of criticism bases its subversive and critical purchase on the combination of negative criticism and diagnosis. Such critical diagnosis depends on the interrogation, questioning, and problematization of concrete features of a political context. The emphasis on the need for a realistic political theory to focus on relations of power 
requires a reconceptualization of the concept of power from being normatively sanctioned in either a positive or negative way to expressing contextually specific techniques and rationalities. This reconceptualization of power stands in close connection to the rejection of the normative qualification and broadening of the understanding of politics, whilst holding on to the critical-diagnostic task of political theorizing which, through its development of evaluative criteria for specific aspects of a political context, cannot help but be normative. The triangle of his emphasis on the entanglement between the descriptive and the normative, his commitment to bringing together the critical impulses to reflection and intervention, and the way he uses negative criticism for the interrogation of the status quo opens up the possibility of developing an understanding of the bases of critical purchase of political theory, the normativity of its criticism, which does not depend on the introduction of moral criteria external to the context in question. In reaction to the inner normativity of historical reality, Geuss' takes the power of the imagination seriously, i.e. to give the importance of the utopian imaginary its due in the way political questions are construed and argued out, without thereby neglecting the close diagnosis of the actual, but rather bringing the contestability of the actual into view. This entails a changed understanding of the relationship between political theory and its context which in turn enables him to overcome a self-imposed limitation common in the debates about realism to the choice between an either critical, but impotent or a contextualist but status quo affirming perspective. In sum, Geuss' radicalization of realism in political theory offers a distinctive subversively-critical and reflexive political theory perspective. On the basis of the interpretation of Geuss' realism offered here, realism in political theory could be taken into a new direction, with particular attention to be paid to the relationship between political theory and its context, in particular with regard to the normativity of criticism. My interpretation of Geuss' realism, however, has not been exhaustive. Especially the connection to early Frankfurt School Critical Theory would be a 
fruitful object of future research, particularly with regard to how Geuss' realism could reinvigorate this tradition with the admission of late Foucauldian views. 
${ }^{1}$ See e.g. William Galston, "Realism in Political Theory," European Journal of Political Theory 9 (2010): 385-411; Hans-Jörg Sigwart, "The Logic of Legitimacy: Ethics in Political Realism," The Review of Politics 75 (2013): 407-432; Michael Freeden, "Interpretive and Prescriptive Realism," Journal of Political Ideologies 17 (2012): 1-11; William E. Scheuerman, "The Realist Revival in Political Philosophy, or: Why New is not Always Improved," International Politics 50 (2013): 798-814; Bonnie Honig and Marc Stears, "The New Realism: from Modus Vivendi to Justice," in Political Philosophy versus History? Contextualism and Real Politics in Contemporary Political Thought, ed. Jonathan Floyd and Marc Stears (Cambridge: Cambridge University Press, 2011), 177-205.

2 The most nuanced account of realism as a contender for distinctive approach to political theory published to date has been offered in: Enzo Rossi and Matt Sleat, "Realism in Normative Political Theory", Philosophy Compass 9 (2014): 689-701. Other taxonomies have placed different emphases, particularly on non-ideal theory. See Laura Valentini, "Ideal vs. Non-Ideal Theory: A Conceptual Map," Philosophy Compass 7 (2012): 654-64; Federico Zuolo, "Realism and Idealism," in A Companion to Political Philosophy. Methods, Tools, Topics, ed. Antonella Besussi (Aldershot: Ashgate, 2013), 65-75.

3 Compare Galston, "Realism", and Marc Stears, "Liberalism and the Politics of Compulsion," British Journal of Political Science 37 (2007): 533-553, with Raymond Geus s, Philosophy and Real Politics (Princeton: Princeton University Press, 2008).

${ }^{4}$ See Galston, "Realism".

${ }^{5}$ See Honig and Stears, The New Realism; see also Paul Kelly, 'Rescuing Political Theory from the Tyranny of History," in Political Philosophy versus History? Contextualism and 
Real Politics in Contemporary Political Thought, ed. Jonathan Floyd and Marc Stears (Cambridge: Cambridge University Press, 2011), 13-37.

${ }^{6}$ See Alasdair MacIntyre, "Book Review: Raymond Geuss - Outside Ethics," Notre Dame Philosophical Reviews, $5^{\text {th }}$ March 2006, available at http://ndpr.nd.edu/review.cfm?id=5922 (last accessed on 1 January 2015); Patchen Markell, 'Book Review: Raymond Geuss Philosophy and Real Politics," Political Theory 38 (2010): 172-177 (174); David Sherman, "Review Essay: Philosophy and Real Politics by Raymond Geuss," Social Theory and Practice 35 (2009): 490-497 (497); Samuel Freeman, 'Book Review: Philosophy and Real Politics," Ethics 120 (2009): 175-184 (184).

${ }^{7}$ Glyn Morgan, "The Realism of Raymond Geuss," Government and Opposition 40 (2005): $110-120(111)$.

${ }^{8}$ See Morgan, The Realism of Raymond Geuss, and, in German, Christoph Menke, "Weder Rawls noch Adorno? Raymond Geuss' Programm einer ,realistischen“ Philosophie,” Deutsche Zeitschrift für Philosophie 58 (2010): 445-455, Fabian Freyenhagen and Jörg Schaub, "Hat hier jemand gesagt, der Kaiser sei nackt? Eine Verteidigung der Geussschen Kritik an Rawls' idealtheoretischem Ansatz," Deutsche Zeitschrift für Philosophie 58 (2010): 457-477, and Janosch Prinz, "Wider die ,Zwangsjacke" der gegenwärtigen liberalen politischen Philosophie. Raymond Geuss' politisch-philosophischer Ansatz," Zeitschrift für Politische Theorie 3 (2012): 81-94, for the most comprehensive interpretations of his work to date.

9 Many of the understandings of realism (Valentini, "Ideal vs. Non-Ideal Theory"; Zuolo, "Realism and Idealism") reflect the ambiguity between understanding realism to a considerable extent as a question within a 'non-ideal theory' framework of liberal-normative 
political theory (in Rawlsian and non-Rawlsian versions) and realism as a perspective which affects the conception of political theory from the ground up which may be traced back to William Galston's realism.

${ }^{10}$ Bernard Williams, In the Beginning was the Deed. Realism and Moralism in Political Argument, ed. Geoffrey Hawthorn (Oxford: Princeton University Press, 2005); Matt Sleat, Liberal Realism. A Realist Theory of Liberal Politics (Manchester: Manchester University Press, 2013); Matt Sleat, 'Legitimacy in Realist Thought: Between Moralism and Realpolitik," Political Theory 42 (2014): 314-337.

${ }^{11}$ Raymond Geuss, Glück und Politik. Potsdamer Vorlesungen, ed. Christoph Menke and Andrea Kern (Berlin: Berliner Wissenschaftsverlag, 2004), 135-137, my translation.

12 Ibid.

${ }^{13}$ Ibid., 106-121; see also Raymond Geuss, Public Goods, Private Goods (Oxford: Princeton University Press, 2003²), vii-xiii.

${ }^{14}$ See Geuss, Glück und Politik, 136. For him, “theories like hermeneutics and consensuscentered philosophies (Rawls, Habermas) are hopelessly conformist"(ibid., my translation). One may retort that both Habermas and Rawls aim to break the hold of conformism, or point out the similarities in the motivations of Geuss and Rawls, as Freyenhagen and Schaub in “Hat jemand gesagt, der Kaiser sei nackt". However, from Geuss' point of view, the decisive difference between him and them is arguably not one of motivation, but whether their perspectives on politics actually enable one to question and resist the status quo.

15 Geuss, Philosophy and Real Politics, 29; Raymond Geuss, Outside Ethics (Princeton: Princeton University Press, 2005), 19-29; Raymond Geuss, Morality, Culture and History 
(Cambridge: Cambridge University Press, 1999), 74; see also Menke, "Weder Rawls noch Adorno," 146.

${ }^{16}$ Raymond Geuss, A World Without Why (Princeton: Princeton University Press, 2014), 90; see also Geuss, Public Goods, xviii-xx; Geuss, Philosophy and Real Politics, 95-96.

${ }^{17}$ Geuss, A World Without Why, 80.

18 Ibid.

${ }^{19}$ John Rawls, Political Liberalism (New York: Columbia University Press, 2005²), 137.

${ }^{20}$ Geuss, Philosophy and Real Politics, 96.

${ }^{21}$ Geuss, A World Without Why, 82. Substitutivity is an important element for practicing what Geuss (with Nietzsche) views as the characteristically human tendency to evaluate (see Geuss, Philosophy and Real Politics, 39-40). Whilst Geuss claims that "[e]ven completely radical forms of political criticism will need at least to some extent to be committed to some kind of substitutivity", this may be stretched quite far, so that the substitution may be realized "only retrospectively" (A World Without Why, 85) or the substitution might take place on an abstract level.

${ }^{22}$ Raymond Geuss, Politics and the Imagination (Princeton: Princeton University Press, 2010), 41 .

${ }^{23}$ Michel Foucault, "What is Enlightenment?" in The Essential works of Foucault, vol. I: Ethics: Subjectivity Truth, ed. Paul Rabinow (New York: The New Press, 1997), 303-319; Michel Foucault, “The Subject and Power," Critical Inquiry 8 (1982): 777-795.

${ }^{24}$ Geuss, Politics and the Imagination, 110. 
${ }^{25}$ Ibid.

${ }^{26}$ Geuss, Philosophy and Real Politics, 16-17.

${ }^{27}$ Geuss, Politics and the Imagination, 12.

28 Raymond Geuss, "Realismus, Wunschdenken, Utopie," Deutsche Zeitschrift für Philosophie 58 (2010): 419-429 (422), my translation. Apart from the use of concepts in political theorizing and politics more generally, Geuss is particularly interested in the tensions between the empirical and transcending aspects of political concepts.

${ }^{29}$ Raymond Geuss, "Wer das Sagen hat," Mittelweg 3620 (2011-2012): 3-12 (10), my translation.

${ }^{30}$ Hans Sluga, Politics and the Search for the Common Good (Cambridge: Cambridge University Press, 2014), 32.

${ }^{31}$ Hans Sluga, "Von der normativen Theorie zur diagnostischen Praxis," Deutsche Zeitschrift für Philosophie 59 (2011): 819-833 (830-831).

32 See Alan Hamlin and Zofia Stemplowska, "Theory, Ideal Theory, and the Theory of Ideals," Political Studies Review 10 (2012): 48-62.

${ }^{33}$ Geuss, A World Without Why, 143.

${ }^{34}$ Sluga, "Von der normativen Theorie zur diagnostischen Praxis," 829.

${ }^{35}$ Michael Theunissen cited in Rahel Jaeggi, “'No individual can resist': Minima Moralia as a Critique of Forms of Life," Constellations 12 (2005): 65-82 (76).

${ }^{36}$ Geuss, "Wer das Sagen hat," 10-11, my translation. 
${ }^{37}$ Geuss, Outside Ethics, 159.

${ }^{38}$ Geuss, "Wer das Sagen hat," 11, my translation.

${ }^{39}$ Geuss, 'Realismus, Wunschdenken, Utopie," 427.

${ }^{40}$ Geuss, Philosophy and Real Politics, 50-55.

${ }^{41}$ See Raymond Geuss, "Realism, Wishful Thinking and Utopia. A talk by Raymond Geuss at the Institute for Advanced Study," University of Minnesota, $6^{\text {th }}$ May 2010, available at http://ias.umn.edu/2010/05/06/geuss-raymond-2/ (last accessed on 1 January 2015).

${ }^{42}$ Geuss, Philosophy and Real Politics, 25.

${ }^{43}$ See Geuss in Janosch Prinz, 'Zwischen kritischer Reflexion und Handlungsorientierung. Gespräch mit Raymond Geuss zu seinem Ansatz in der politischen Philosophie am 01. Juni 2010 in der Faculty of Philosophy der Universität Cambridge," Zeitschrift für Politische Theorie 3 (2012): 95-108 (102); see also "Raymond Geuss on Realism and Utopianism in Political Philosophy," Interview with David Edmonds and Nigel Warburton for the Philosophy Bites series, $8^{\text {th }}$ May 2010, available at http://philosophybites.com/2010/05/raymond-geuss-on-realism-in-political-philos ophy.html (last accessed on 1 January 2015).

${ }^{44}$ Geuss, 'Realismus, Wunschdenken, Utopie,” 427-428.

${ }^{45}$ Barry Hindess, Discourses of Power. From Hobbes to Foucault (Oxford: Blackwell, 1996).

${ }^{46}$ Geuss, Philosophy and Real Politics, 26-28, 97.

47 This connects directly with Foucault's goal of the analysis of relations of power. Geuss' comment in Philosophy and Real Politics (21) suggests that he also shares the view that even 
in repressive regimes there are spaces of freedom which would then meet Foucault's acc ount of agency required for the exercise of power as developed in "The Subject and Power".

${ }^{48}$ Geuss in Prinz, “Zwischen kritischer Reflexion und Handlungsorientierung,” 102.

${ }^{49}$ See also Geuss, Outside Ethics, 153-160; Geuss, A World Without Why, xvi.

${ }^{50}$ See Hindess, Discourses of Power, 111-112, 135.

${ }^{51}$ Michel Foucault, 'La philosophie analytique de la politique," in Foucault, Michel: Dits et Écrits 1954-1988, volume II, 1976-1988, ed. Daniel Defert and François Ewald (Paris: Quarto Gallimard, 2001), 534-551 (540, my translation).

${ }^{52}$ See Michel Foucault, Security, Territory, Population, Lectures at the Collège de France 1977-1978, ed. Michel Sennellart, trans. Graham Burchell (Basingstoke: Palgrave Macmillan, 2007), 195ff.

53 This has implications for the understanding of freedom and the relationship between power and freedom, leading to a minimally normative understanding of power which depends on agency for those over whom power is exercised. Power is hence categorically distinguished from violence, not from domination.

${ }^{54}$ See Michel Foucault, Truth and Power, in Power/Knowledge. Selected Interviews and Other Writings 1972-1977 by Michel Foucault, ed. Colin Gordon (New York: Pantheon Press, 1980), 109-133; Foucault, Security, Territory, Population.

55 Geuss, Philosophy and Real Politics, 25.

${ }^{56}$ Raymond Geuss, “Economies: Good, Bad, Indifferent,” Inquiry 55 (2012): 331-360.

${ }^{57}$ Geuss, Morality, Culture and History, 51-77; Raymond Geuss, History and Illusion in Politics (Cambridge: Cambridge University Press, 2001). 
${ }^{58}$ Foucault, "La philosophie analytique de la politique," 540, translation quoted from Michel Sennellart, "Course Context," in Michel Foucault: Security, Territory, Population. Lectures at the Collège de France 1977-1978, ed. Michel Sennellart, trans. Graham Burchell (Basingstoke: Palgrave Macmillan, 2007), 368-401 (374).

${ }^{59}$ Foucault, “La philosophie analytique de la politique," 541, my translation.

${ }^{60}$ See e.g. Raymond Geuss, 'Der Markt soll alles wieder richten. Sind Geisteswissenschaften nur Flitterwerk? Die englische Regierung will sie finanziell austrocknen," Die Zeit, 10th March 2011, available at http://www.zeit.de/2011/11/Englische-Unis (last accessed on 1 January 2015); Raymond Geuss, 'Da hilft nur eine ganz andere Politik!,” 10th August 2011, available at http://www.tagesschau.de/inland/geuss100.html (last accessed on 1 January 2015); Raymond Geuss, "Aufruf zum Widerstand. Neoliberalismus als Wurzel der Krawalle," $13^{\text {th }}$ August 2011, available at http://oe1.orf.at/artikel/283602 (last accessed on 1 January 2015).

${ }^{61}$ Raymond Geuss, "Philosophical Anthropology and Social Criticism," in Axel Honneth: Reification. A New Look at an Old Idea, ed. Martin Jay (Oxford: Oxford University Press, 2008), pp. 120-131.

${ }^{62}$ Geuss, A World Without Why, 147.

${ }^{63}$ Ibid.

${ }^{64}$ Ibid, 150.

${ }^{65}$ Sleat, Liberal Realism; Williams, In the Beginning was the Deed, 1-17.

${ }^{66}$ Geuss, Outside Ethics, 39.

${ }^{67}$ Geuss, A World Without Why, 140. 
68 See Geuss, Public Goods, Private Goods, xvii; Geuss, Glück und Politik, 125; Geuss, History and Illusion in Politics, vii-viii.

${ }^{69}$ Geuss, History and Illusion in Politics, 9-10.

70 Geuss in Quentin Skinner et al., "Political Philosophy: The View from Cambridge," Journal of Political Philosophy 10 (2002): 1-19 (7).

${ }^{71}$ Geuss, "Wer das Sagen hat," 3.

${ }^{72}$ Geuss, Politics and the Imagination, 4-6.

${ }^{73}$ Geuss, Philosophy and Real Politics, 97. This opens up the possibility of expanding the scope of political theorizing beyond the written and spoken word toward a closer look at the non-verbal. Geuss e.g. uses the attack of $9 / 11$ as an example of non-verbal political act (Politics and the Imagination, 16). Elsewhere (Politics and the Imagination, 154) he elaborates on this theme: "That there is no philosophy without language might not mean that the only thing, or even the most important thing, one had to understand in the history of philosophy was its language. Song is not speech, and political action, even if it 'can be understood,' can take place without a word being spoken."

${ }^{74}$ Geuss, "Realismus, Wunschdenken, Utopie," 428, my translation.

75 "Raymond Geuss on Realism and Utopianism in Political Philosophy"; see also Geuss, "Realismus, Wunschdenken, Utopie," 429.

${ }^{76}$ Geuss, Politics and the Imagination, 41.

${ }^{77}$ Geuss, Glück und Politik, 52-57. 
78 This is not the place for a comprehensive assessment of these debates. As mentioned above, the realisms inspired by Bernard Williams such as by Matt Sleat, e.g. in his Liberal Realism and in his "Between Moralism and Realpolitik", are particularly interesting as they involve a high level of criticism of political theory as based on moral or legal philosophy, understood as applied ethics or generally operating ahistorically with universal aspirations. They also focus on the partisanship and the power involved in political theorizing, as well as the need to integrate the reality of domination in overall legitimate political regimes into political theorizing.

${ }^{79}$ For a brief discussion of Williams with regard to the example of legitimacy see Jörg Schaub, "Warum es einer von Idealtheorien unabhängigen politischen Theorie der Legitimität bedarf," in Der Aufstieg der Legitimitätspolitik. Rechtfertigung und Kritik politischökonomischer Ordnungen, ed. Christopher Daase, Anna Geis and Frank Nullmeier (BadenBaden: Nomos, 2012), 436-451 (447).

${ }^{80}$ Sleat, "Between Moralism and Realpolitik," 331.

${ }^{81}$ See Bernard Williams, Truth and Truthfulness (Princeton: Princeton University Press, 2002), 225-232; Williams, In the Beginning was the Deed, 6.

${ }^{82}$ Valentini, "Ideal vs. Non-Ideal Theory,” 659.

${ }^{83}$ See Freeden, 'Interpretive and Prescriptive Realism"; Hamlin and Stemplowska, "Theory, Ideal Theory, and the Theory of Ideals".

${ }^{84}$ See Sleat, "Between Moralism and Realpolitik".

${ }^{85}$ See Galston, "Realism,” 401-402. 
Pablo Gilabert and Holly Lawford-Smith, "Political Feasibility. A Conceptual Exploration," Political Studies 60 (2012): 809-825.

${ }^{87}$ See Honig and Stears, "The New Realism"; Williams, In the Beginning was the Deed, 25, $55-61$

${ }^{88}$ Lorna Finlayson, "With Radicals like these," European Journal of Political Theory (2015/forthcoming).

${ }^{89}$ Geuss, Outside Ethics, 27-28; Geuss, A World Without Why, 68-90.

${ }^{90}$ Geuss, History and Illusion in Politics; Geuss, Public Good, Private Goods; Geuss, Politics and the Imagination.

${ }^{91}$ Geuss, "Wer das Sagen hat"; Geuss, History and Illusion in Politics, 37-42; Ge us s, Glück und Politik, 126.

92 Raymond Geuss, “Human Rights - A Bad Idea,” Theoria 60 (2012): 83-103 (89-90). 